\title{
Development from Alloys to Nanocomposite for an Enhanced Mechanical and Ignition Response in Magnesium
}

\author{
Khin Sandar Tun ${ }^{1}$ (D), Tan Yan Shen Brendan ${ }^{1}$, Sravya Tekumalla ${ }^{2}$ and Manoj Gupta ${ }^{1, *(D)}$ \\ 1 Department of Mechanical Engineering, Faculty of Engineering, Kent Ridge Campus, National University of \\ Singapore, Singapore 637551, Singapore; mpekhst@nus.edu.sg (K.S.T.); \\ Tanyanshenbrendan@gmail.com (T.Y.S.B.) \\ 2 College of Engineering, School of Mechanical and Aerospace Engineering, Nanyang Technological University, \\ Singapore 637551, Singapore; sravya.tekumalla@ntu.edu.sg \\ * Correspondence: mpegm@nus.edu.sg; Tel.: +65-6516-6358
}

Citation: Tun, K.S.; Brendan, T.Y.S.

Tekumalla, S.; Gupta, M.

Development from Alloys to Nanocomposite for an Enhanced Mechanical and Ignition Response in Magnesium. Metals 2021, 11, 1792. https://doi.org/10.3390/met11111792

Academic Editor: Marcello Cabibbo

Received: 28 September 2021

Accepted: 5 November 2021

Published: 8 November 2021

Publisher's Note: MDPI stays neutral with regard to jurisdictional claims in published maps and institutional affiliations.

Copyright: (c) 2021 by the authors. Licensee MDPI, Basel, Switzerland. This article is an open access article distributed under the terms and conditions of the Creative Commons Attribution (CC BY) license (https:/ / creativecommons.org/licenses/by/ $4.0 /)$.

\begin{abstract}
The current study reports on the evolution of microstructure, variations in compressive properties and the ignition resistance of $\mathrm{Mg}$ through compositional variation, using alloying elements and nanoreinforcement. The alloys were designed with the use of a singular alloying element, $\mathrm{Ca}$, and a binary alloying element, $\mathrm{Ca}+\mathrm{Sc}$, to develop $\mathrm{Mg} 1 \mathrm{Ca}$ (wt.\%) and Mg1Ca1Sc (wt.\%) alloys. $\mathrm{B}_{4} \mathrm{C}$ nanoparticles were addedas the reinforcement phase in the Mg1Ca1Sc alloy to create the $\mathrm{Mg} 1 \mathrm{Ca} 1 \mathrm{Sc} / 1.5 \mathrm{~B}_{4} \mathrm{C}$ (wt.\%) nanocomposite. The most effective compressive properties and level of ignition resistance was displayed by the developed composite. The grain sizes were significantly reduced in the Mg alloys (81\%) and the composite (92\%), compared with that of the Mg. Overall, the microstructural features (i.e., grain refinement, the formation of favorable intermetallic compounds, and hard reinforcement particles with an adequate distribution pattern) enhanced both the compressive strength and strain of the alloys and the composite. The ignition resistance was progressively increased from the alloys to the nanocomposite, and a peak ignition temperature of $752{ }^{\circ} \mathrm{C}$ was achieved in the composite. When compared with the ignition resistant of Elektron 21 (E21) alloy, which met the Federal Aviation Administration (FAA) requirements, the $\mathrm{Mg} 1 \mathrm{Ca} 1 \mathrm{Sc} / 1.5 \mathrm{~B}_{4} \mathrm{C}$ nanocomposite showed a higher specific yield strength and better ignition resistance, asserting it as a potential candidate material for lightweight engineering applications, including aerospace and defense sectors.
\end{abstract}

Keywords: magnesium alloys; composite; grain refinement; ignition temperature; compressive properties

\section{Introduction}

Due to the concerns surrounding global warming in modern times, there is a significant need to reduce the global levels of carbon dioxide emissions. Moreover, there has been a recent lift in the ban of magnesium-based materials in aircrafts by the Federal Aviation Administration (FAA). Given that magnesium has similar mechanical properties to aluminum, which is commonly used in aircrafts, this allows for a reduction in weight of the aircraft of up to $28 \%$ to $30 \%$, should the aluminum components-such as those in the seat elements-be replaced with magnesium [1]. Due to the reduction in the weight of the aircraft, the aircraft would be able to consume less fuel per trip. This not only reduces carbon dioxide emissions, which reduces the carbon footprint of the aviation industry, but also reduces the operating costs of the aviation industry by consuming less fuel.

To be suited to targeted structural applications, the mechanical properties of pure $\mathrm{Mg}$ have been continuously enhanced by alloying and composite technologies. To be applicable in the aviation industry, magnesium-based materials must possess not only enhanced mechanical properties, but also enhanced ignition properties. It is necessary to choose promising alloying elements and reinforcement particles which can satisfy the required mechanical and ignition properties. Commercially available Mg alloys such as 
$\mathrm{Mg}-\mathrm{Al}-\mathrm{Zn}$ alloys (AZ series magnesium alloys) are widely used in various structural applications, due to their suitable mechanical properties. Although the use of the alloying element $\mathrm{Al}$ can improve the alloys' mechanical properties, it is not effective in improving the ignition resistance of magnesium [2-4]. One of the reasons for the occurrence of a low ignition temperature in $\mathrm{Al}$-containing $\mathrm{Mg}$ alloys is due to the formation of a lowmelting-temperature phase, $\mathrm{Mg}_{17} \mathrm{Al}_{12}$. The ignition temperature of $\mathrm{Mg}-\mathrm{Al}$ alloys can be even lower than that of pure $\mathrm{Mg}[3,4]$. In previous studies, the ignition resistance of $\mathrm{AZ}$ series magnesium alloys has been seen to increase using $\mathrm{Ca}$ as an additional alloying element [5-8]. The addition of $\mathrm{Ca}$ can contribute to the increase in ignition temperature in the $\mathrm{Mg}-\mathrm{Al}$ alloy by increasing the formation of the $\mathrm{CaO}$ oxide layer, consequently increasing the onset melting temperature of the $\mathrm{Mg}_{17} \mathrm{Al}_{12}$ phases and the formation of the thermally stable $\mathrm{Al}_{2} \mathrm{Ca}$ phases [6,7]. In addition, the use of $\mathrm{Ca}$ also assists in the further improvement of mechanical properties in the base $\mathrm{Mg}$ alloy. Generally, the improved mechanical properties in calcium-containing $\mathrm{Mg}$ alloys occurs through microstructure evolution, such as grain refinement and secondary phase formation [9-12]. Besides $\mathrm{Ca}$, rare earth elements (REs) are reported as excellent ignition-resistance enhancers [2]. Although the addition of REs can improve the stability of the oxide layer and the ignition resistance of the $\mathrm{Mg}$ alloys, the oxidation resistance and ignition behaviour of the alloys strongly depend on the alloy composition, microstructure, and solubility limit of alloying elements (REs). Zhao et al. [13] reported a decrease in the ignition resistance of the AZ91D/Nd alloy with the use of low $\mathrm{Nd}$ content at $0.5 \mathrm{wt} . \%$; however, an increase in the ignition temperature was noted with the use of high $\mathrm{Nd}$ content at $5 \mathrm{wt} . \%$. On the other hand, a decrease in the ignition temperature of the $\mathrm{Mg}$ alloys containing REs such as $\mathrm{La}, \mathrm{Pr}$, and $\mathrm{Ce}$, which have very low solid solubility in $\mathrm{Mg}$, was also reported [3].

The aim of the current study was to use Ca as an alloying element for the improvement of both mechanical and ignition properties. Due to the important role of $\mathrm{Ca}$ in increasing the ignition temperature and high-temperature oxidation resistance of $\mathrm{Mg}$, calcium-containing magnesium-based alloys and composites have been designed systemically. In our study, Ca was first used as singular alloying element in $\mathrm{Mg}$, creating the $\mathrm{Mg} 1 \mathrm{Ca}$ (wt.\%) alloy. Then, 1 wt.\% Sc was added as an additional alloying element into the Mg1Ca alloy, to study the combined effect of $\mathrm{Ca}$ and Sc, with the expectation that it would enhance the mechanical and ignition properties of the Mg1Ca1Sc alloy. A favorable ignition response was projected from the alloy, considering the high solubility limit ( 16 at.\%) of Sc in Mg [14]. Finally, $\mathrm{B}_{4} \mathrm{C}$ nanoparticle reinforcement was added into the Mg1Ca1Sc alloy to develop the $\mathrm{Mg}$ alloy composite. The selection of $\mathrm{B}_{4} \mathrm{C}$ for the reinforcement phase was based on previous studies $[15,16]$ which have reported the advantages of using this reinforcement phase in improving the mechanical and ignition properties of $\mathrm{Mg}$ and $\mathrm{Mg}$ alloys.

\section{Processing and Characterization}

The $\mathrm{Mg}$ alloys and composite $\left(\mathrm{Mg} 1 \mathrm{Ca}\right.$ and $\mathrm{Mg} 1 \mathrm{Ca} 1 \mathrm{Sc}$ and $\left.\mathrm{Mg} 1 \mathrm{Ca} 1 \mathrm{Sc} / 1.5 \mathrm{~B}_{4} \mathrm{C}\right)$ were synthesized using the disintegrated melt deposition (DMD) technique. The compositions used for the alloys and composite were in weight percentage; magnesium turnings ( $>99.9 \%$ purity, ACROS Organics, Morris Plains, NJ, USA), Mg-30Sc master ingots (99.9\% purity, Sunrelier Metal Company Shanghai, China), Calcium granules (99.8\% purity, Alfa Aesar, Massachusetts, United States) and $\mathrm{B}_{4} \mathrm{C}$ nanoparticles of $\sim 50 \mathrm{~nm}$ size (Nabond, Shenzhen, China) were used as raw materials for the materials preparation. The raw materials were weighed in accordance with the designated compositions and placed in a graphite crucible. The materials were heated to $750{ }^{\circ} \mathrm{C}$ using an electrical resistance furnace in an atmosphere of inert argon gas. The molten melt was poured through a nozzle of $10 \mathrm{~mm}$ diameter at the bottom of the crucible, to the mold below the crucible. Two jets of argon gas, oriented normal to the melt stream, were used to disintegrate the molten metal before it entered the mold. The disintegrated melt was then deposited into the cylindrical mold of $40 \mathrm{~mm}$ diameter. This ingot was later machined to $36 \mathrm{~mm}$ diameter and used for the secondary process of extrusion. The cast ingot was homogenized at $400{ }^{\circ} \mathrm{C}$ for $1 \mathrm{~h}$, followed by hot 
extrusion at $350{ }^{\circ} \mathrm{C}$, using a 150-tonne hydraulic extrusion press The extrusion ratio of 20.25:1 was used to obtain the extruded rods of $8 \mathrm{~mm}$.

Microstructural characterization was performed using a JEOL JSM-6010 scanning electron microscope (JEOL Ltd., Tokyo, Japan), equipped with energy dispersive X-ray analysis (EDX, JEOL Ltd., Tokyo, Japan), to analyze the grain size, phase morphology, phase compositions, and distribution pattern of grains and secondary phases in the developed materials. MATLAB analysis software (R2013b, MathWorks, Massachusetts, USA) was used to measure the grain size in the Mg alloys and the composite. The room temperature compressive tests were performed on the samples in conformation with the procedures detailed in the Standard ASTM E9-89a, using a fully automated MTS810 servo-hydraulic test machine (MTS systems corporation, Eden Prairie, MN, USA). Cylindrical samples with a length to diameter ratio of 1 were used for compressive testing. The ignition temperatures of the materials were determined using a Thermo Gravimetric Analyzer (TGA, Netzsch Selb, Germany). Samples with dimensions of approximately $2 \mathrm{~mm} \times 2 \mathrm{~mm} \times 1 \mathrm{~mm}$ were placed in purified air with a flow rate of $50 \mathrm{~mL} / \mathrm{min}$. They were heated from 30 to $1000{ }^{\circ} \mathrm{C}$ at a heating rate of $10{ }^{\circ} \mathrm{C} / \mathrm{min}$. A graph of temperature vs. time was obtained from the test. The point at which the rapid change in temperature was observed in the graph was recorded as the ignition temperature of the materials.

\section{Results and Discussion}

\subsection{Microstructure Evolution in Alloys and Composite}

Figure 1 represents the microstructures of the alloys and composite. The presence of secondary phases was analyzed through EDX analysis, as shown in Figure 2. Based on the $\mathrm{Mg}-\mathrm{Ca}$ binary phase diagram [17], there was very low solid solubility of $\mathrm{Ca}$ in $\mathrm{Mg}\left(0.82\right.$ at.\%). Consequently, the formation of $\mathrm{Mg}_{2} \mathrm{Ca}$ is a common finding in calciumcontaining $\mathrm{Mg}$ alloys [9-12]. In the present study, the formation of the intermetallic compound, $\mathrm{Mg}_{2} \mathrm{Ca}$, was also observed in the alloys $\mathrm{Mg} 1 \mathrm{Ca}$ and $\mathrm{Mg} 1 \mathrm{Ca} 1 \mathrm{Sc}$, and the composite $\mathrm{Mg} 1 \mathrm{Ca} 1 \mathrm{Sc} / \mathrm{B}_{4} \mathrm{C}$. The presence of the $\mathrm{Mg}_{2} \mathrm{Ca}$ phase was confirmed through elemental analysis, using EDX as seen in Figure 2. As shown in Figure $1 \mathrm{a}$, the $\mathrm{Mg}_{2} \mathrm{Ca}$ phases were uniformly distributed in the extruded Mg1Ca alloy, with minimal presence of clusters. Following the addition of $\mathrm{Sc}$ as an additional alloying element in the Mg1Ca1Sc alloy and its composite, the formation of the $\mathrm{Mg}-\mathrm{Sc}$ phase [18], together with the $\mathrm{Mg}_{2} \mathrm{Ca}$ phases, can be seen in the micrographs in Figure 1b,c and Figure 2b,c. Through the EDX mapping results shown in Figure 3, the fine phases were confirmed to be the $\mathrm{Mg}_{2} \mathrm{Ca}$ phase and coarse phase was confirmed as the $\mathrm{Mg}-\mathrm{Sc}$ phase. The tendency for the clustering of phases was relatively higher in the Mg1Ca1Sc alloy compared with the Mg1Ca alloy. In the composite, besides the presence of the $\mathrm{Mg}_{2} \mathrm{Ca}$ and $\mathrm{Mg}-\mathrm{Sc}$ phases, the reinforcement particles $\mathrm{B}_{4} \mathrm{C}$ can be seen in the micrograph in Figures 1c and 2c. From the EDX analysis in Figure 2c, it can be seen that the element $B$ was not detected, but a low intensity peak of carbon, $\mathrm{C}$, was found instead. This indicates the presence of $\mathrm{B}_{4} \mathrm{C}$ in the composites. The elemental information of $B$ and $C$ was not strong enough to pick up through the EDX analysis, due to very fine and dispersed reinforcement particles (Figures $1 \mathrm{c}$ and $2 \mathrm{c}$ ).

From the composite's microstructure (Figures $1 \mathrm{c}$ and $2 \mathrm{c}$ ), the clustered phases were reduced and a fine dispersion of $\mathrm{Mg}_{2} \mathrm{Ca}$ and $\mathrm{B}_{4} \mathrm{C}$ particles could be found. Overall, the distribution pattern of the secondary phases, $\mathrm{Mg}_{2} \mathrm{Ca}, \mathrm{Mg}-\mathrm{Sc}$ and $\mathrm{B}_{4} \mathrm{C}$, was homogeneous in the composite material. 


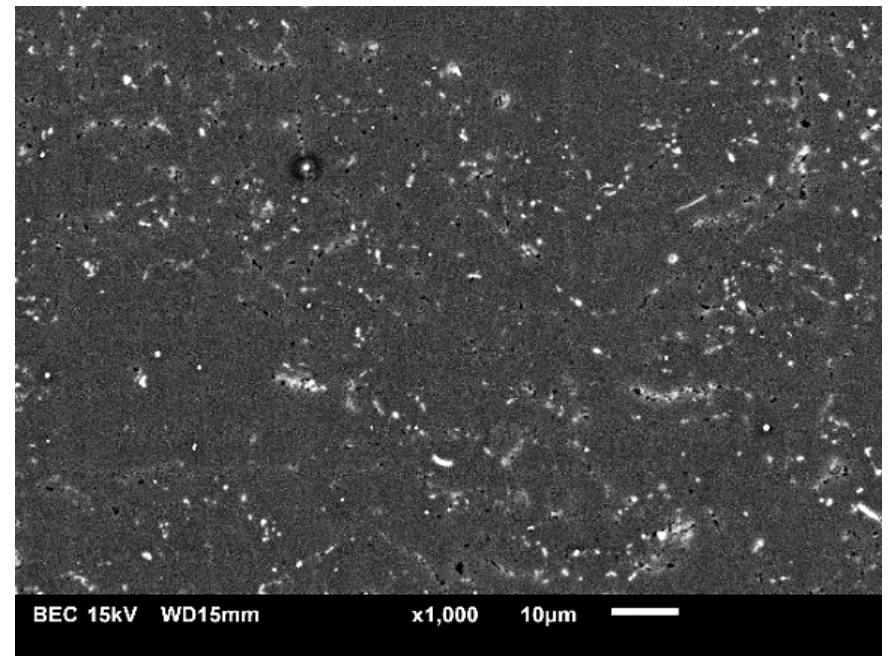

(a)

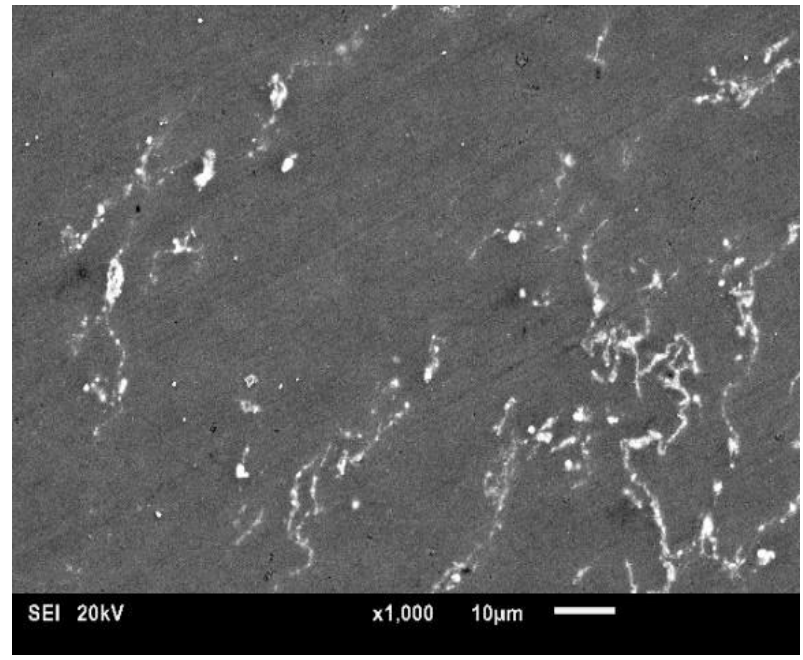

(b)

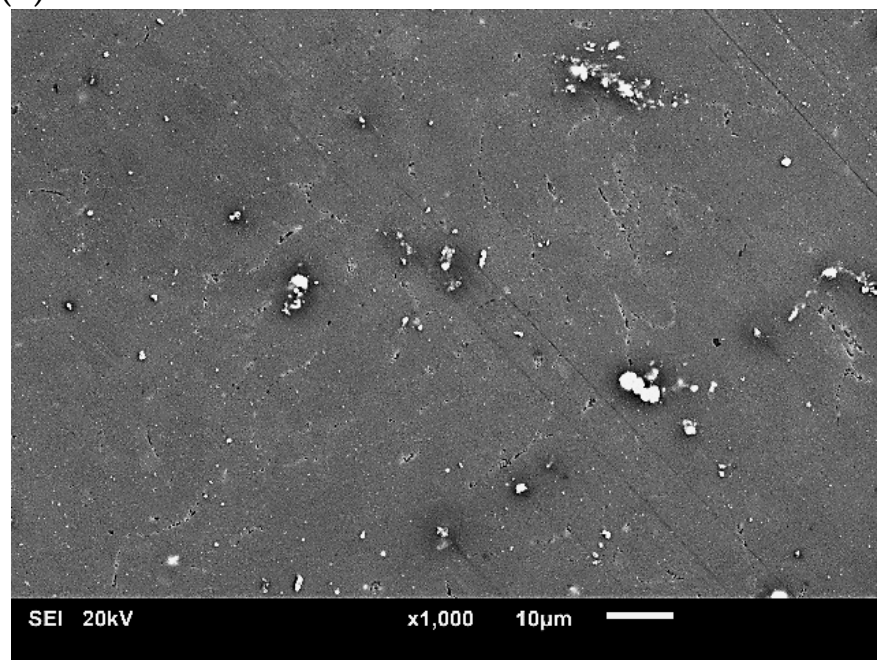

(c)

Figure 1. Formation, distribution, and morphology of secondary phases in: (a) Mg1Ca alloy, (b) Mg1Ca1Sc alloy, and (c) $\mathrm{Mg} 1 \mathrm{Ca} 1 \mathrm{Sc} / \mathrm{B}_{4} \mathrm{C}$ composite.

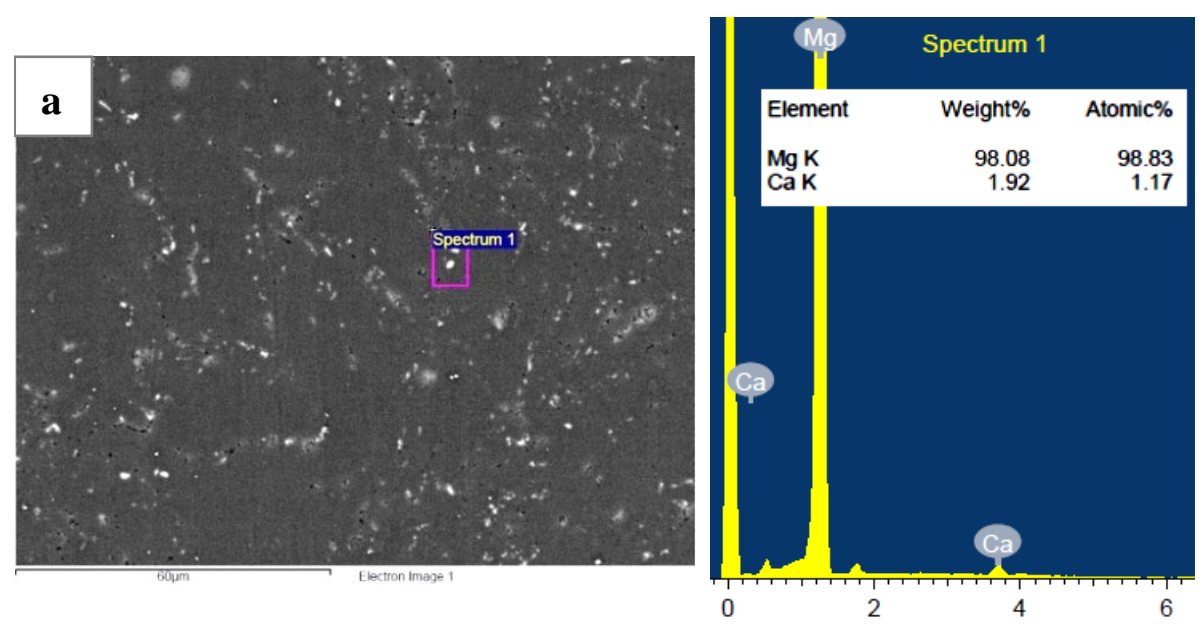

Figure 2. Cont. 

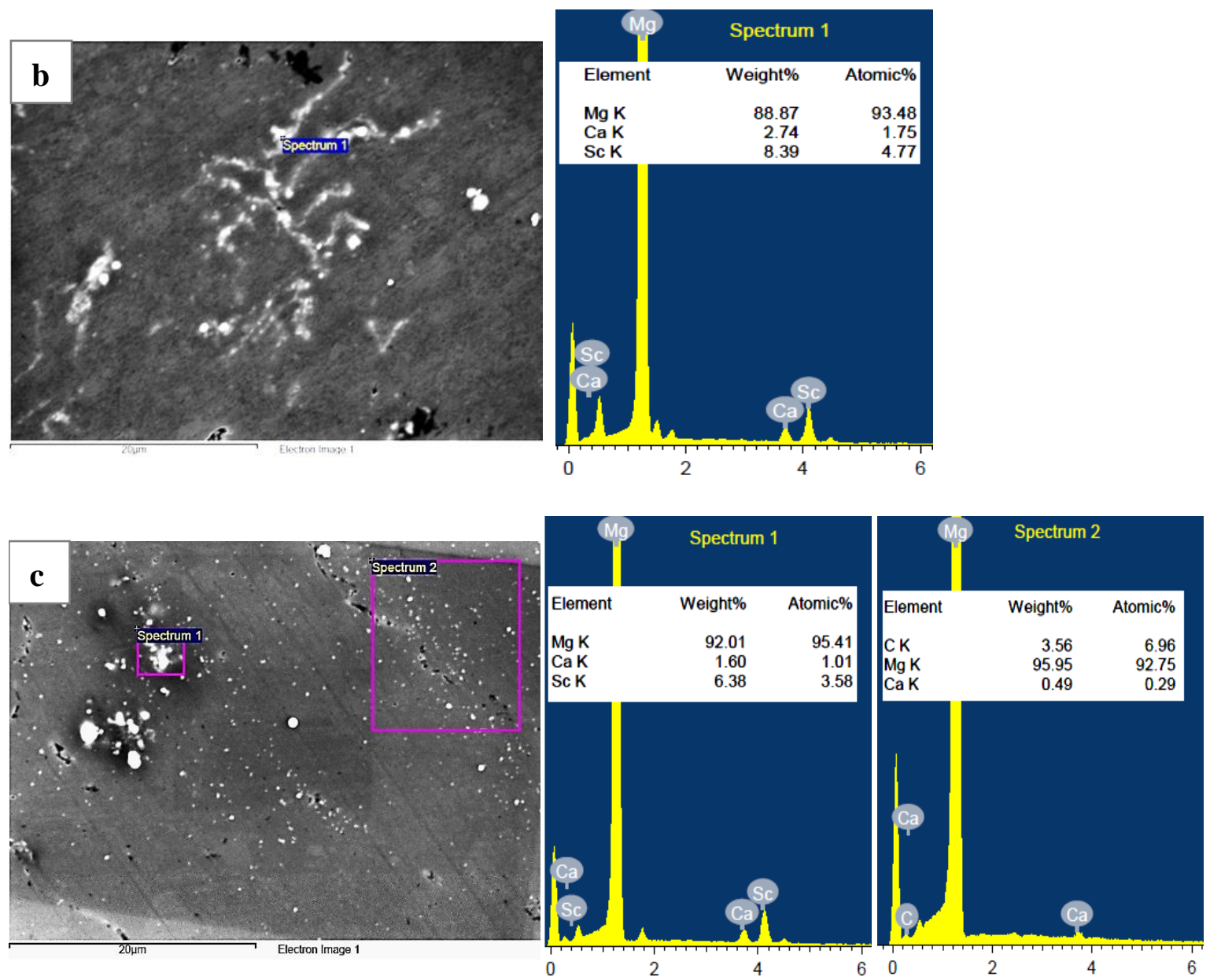

Figure 2. EDX analysis showing: (a) $\mathrm{Mg}$ and Ca peaks in $\mathrm{Mg} 1 \mathrm{Ca}$ alloy, (b) $\mathrm{Mg}$, Ca and Sc peaks in Mg1Ca1Sc alloy and (c) $\mathrm{Mg}, \mathrm{Ca}, \mathrm{Sc}$ and $\mathrm{C}$ peaks in $\mathrm{Mg} 1 \mathrm{Ca} 1 \mathrm{Sc} / 1.5 \mathrm{~B}_{4} \mathrm{C}$ composite.
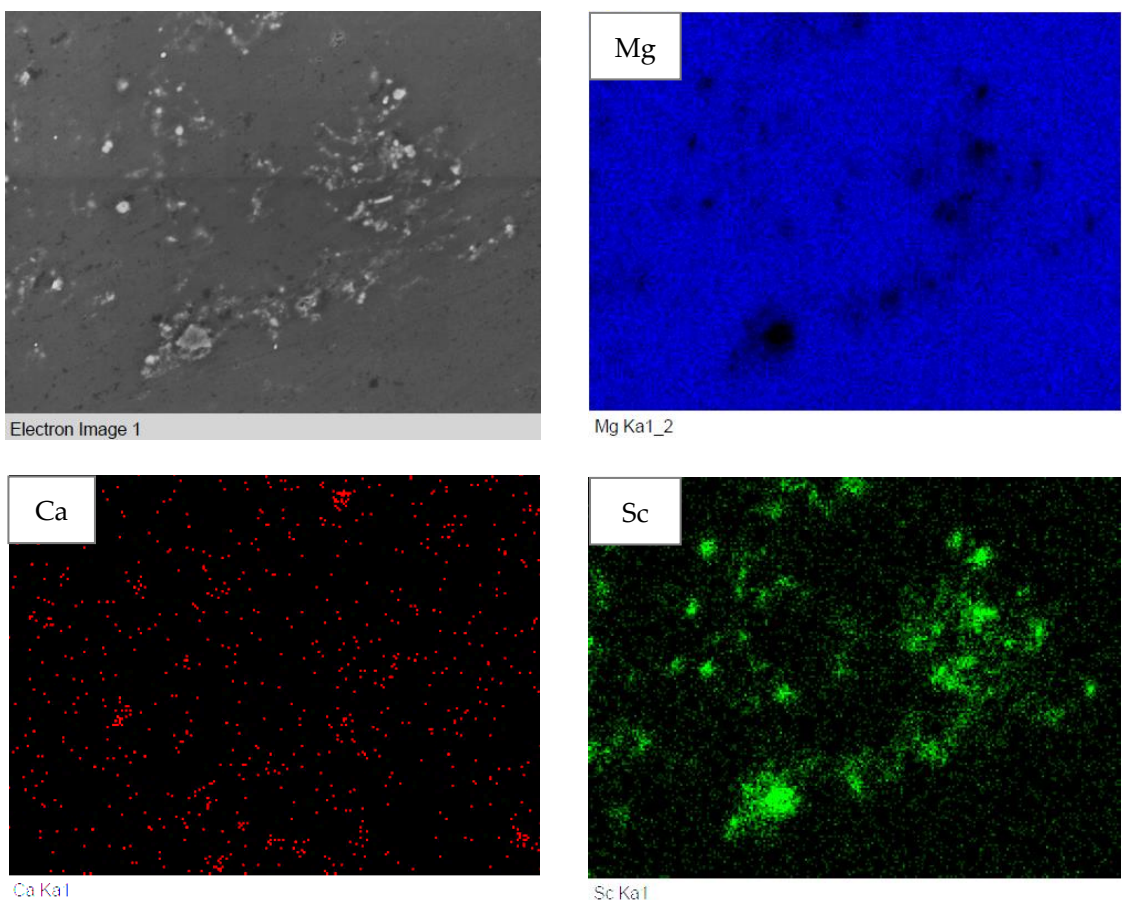

Figure 3. EDX mapping analysis of the Mg1Ca1Sc alloy. 


\subsection{Grain Morphology/Distribution}

Figure 4 shows the SEM micrographs presenting a comparison of grain sizes in pure $\mathrm{Mg}, \mathrm{Mg}$ alloys and the composite. The micrographs were taken along the extrusion direction. All materials revealed a relatively homogeneous grain structure, a nearly equiaxed grain morphology, and the absence of any elongated grains along the extrusion direction. These observations indicated that the grains were fully recrystallized in all extruded materials. As shown in the grain distribution patterns in Figure 4, the alloys and the composite demonstrated a better homogeneous grain size distribution, compared with pure $\mathrm{Mg}$. The average grain sizes were measured to be $21 \pm 6 \mu \mathrm{m}, 4 \pm 1 \mu \mathrm{m}, 4 \pm 1 \mu \mathrm{m}$ and $1.7 \pm 0.4 \mu \mathrm{m}$ for $\mathrm{Mg}$, the $\mathrm{Mg} 1 \mathrm{Ca}$ and $\mathrm{Mg} 1 \mathrm{Ca} 1 \mathrm{Sc}$ alloys and the $\mathrm{Mg} 1 \mathrm{Ca} 1 \mathrm{Sc} / \mathrm{B}_{4} \mathrm{C}$ composite, respectively. The use of alloying elements, $\mathrm{Ca}$ and $\mathrm{Ca}+\mathrm{Sc}$ in $\mathrm{Mg}$ led to a significant grain size reduction in their respective alloys, $\mathrm{Mg} 1 \mathrm{Ca}$ and $\mathrm{Mg} 1 \mathrm{Ca} 1 \mathrm{Sc}$, indicating the effectiveness of the selected alloying elements. However, the combined presence of $\mathrm{Ca}$ and $\mathrm{Sc}$ in the Mg1Ca1Sc alloy did not cause a further reduction in grain size, resulting in the same average grain size as in the Mg1Ca alloy. This can be explained through microstructural observation.

Dynamic recrystallization takes place during deformation, such as during the hot extrusion of the materials. The presence of either mixed grain sizes (coarse grains and fine grains) or elongated grains along the extrusion direction are indicative of incomplete recrystallization. In the current investigation, near equiaxed grains, together with their uniform distribution pattern observed in all the materials, indicated that full recrystallization happened via dynamic recrystallization during hot extrusion (Figure 4). For magnesium-based materials containing certain types of intermetallic compounds or reinforcement particles (secondary phases), those phases can act as the source to stimulate the recrystallization process. The nucleation of new grains occurs at the deformation zone around hard secondary phases, or particles during hot extrusion, which is generally known as particle-stimulated nucleation (PSN). In the microstructure of the Mg1Ca alloy (Figures 1a and 2a), well distributed $\mathrm{Mg}_{2}$ Ca phases can be seen. A remarkable grain size reduction of $81 \%$ was observed in the $\mathrm{Mg} 1 \mathrm{Ca}$ alloy, compared with $\mathrm{Mg}$, and therefore the potential capability of the $\mathrm{Mg}_{2} \mathrm{Ca}$ phases to play a critical role in the grain refinement of $\mathrm{Mg}$ through particle-stimulated dynamic recrystallization during hot extrusion is envisaged. When compared with the Mg1Ca alloy, the same average grain size, as well as a similar grain distribution pattern, was observed in the Mg1Ca1Sc alloy (Figure $4 b, c)$. As seen in the microstructure of the Mg1Ca1Sc alloy, the addition of Sc to the Mg1Ca alloy caused the increased clustering $\left(\mathrm{Mg}_{2} \mathrm{Ca}+\mathrm{Mg}-\mathrm{Sn}\right)$ of secondary phases (Figure $\left.2 \mathrm{~b}\right)$, while maintaining the distribution pattern of $\mathrm{Mg}_{2} \mathrm{Ca}$ phases based on the EDX analysis in Figure 3. This meant that the distribution pattern of the secondary phases between the $\mathrm{Mg} 1 \mathrm{Ca}$ and Mg1Ca1Sc alloys was the same, and the formation of the additional Mg-Sc phases only caused clustered phases. Further grain refinement would only be possible if there was a balance between the increased second phases and their relative uniformity of distribution $[19,20]$. This explains the lack of further grain refinement in the Mg1Ca1Sc alloy. In the case of the Mg1Ca1Sc/ $\mathrm{B}_{4} \mathrm{C}$ composite, the particle reinforcement caused a $58 \%$ reduction in grain size in relation to the Mg1Ca1Sc alloy, and $92 \%$ reduction in relation to $\mathrm{Mg}$. This clearly shows that the fine $\mathrm{B}_{4} \mathrm{C}$ particulates had a strong capability in grain growth restriction through the classical grain-boundary pinning mechanism $[15,16]$. In addition, the homogeneous grain-distribution pattern was attained (Figure $4 \mathrm{~d}$ ) as a consequence of microstructural homogeneity, in terms of good second phase distribution in the composite (Figures 1c and 2c). 

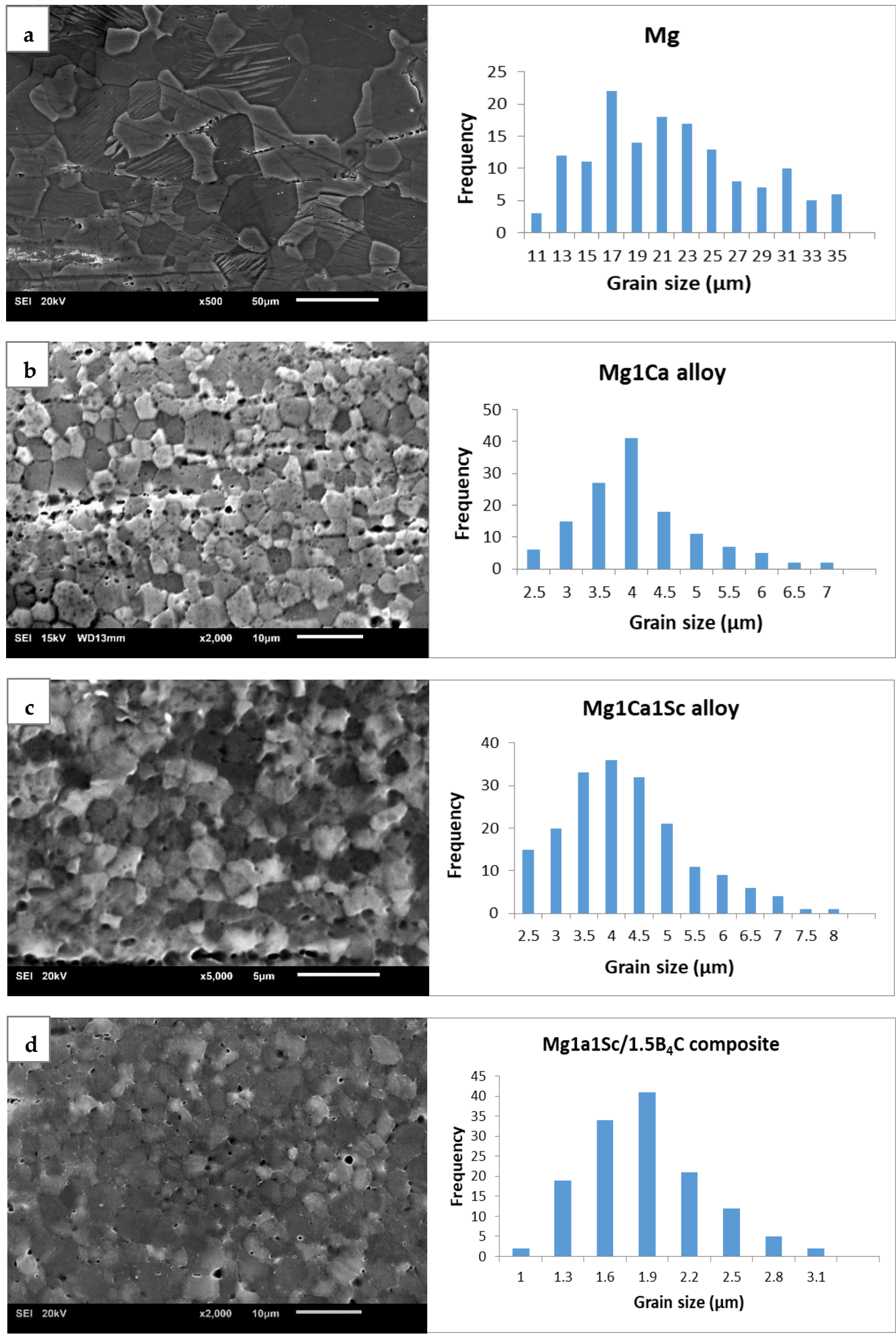

Figure 4. SEM micrographs showing grain sizes and distribution patterns in: (a) $\mathrm{Mg}$, (b) Mg1Ca alloy, (c) Mg1Ca1Sc alloy and (d) $\mathrm{Mg} 1 \mathrm{Ca} 1 \mathrm{Sc} / \mathrm{B}_{4} \mathrm{C}$ composite. 


\subsection{Ignition Properties}

The ignition temperature of magnesium can be increased by alloying and composite methods, using suitable alloying elements and reinforcement materials. The ignition temperatures of the $\mathrm{Mg}$ alloys and composite developed in this study are shown in Figure 5. The addition of the alloying element $\mathrm{Ca}$ has been proven to increase the ignition properties of $\mathrm{Mg}$ [5-8]. The Mg1Ca alloy developed in the current study also showed the improved ignition temperature of $11 \%$ over $\mathrm{Mg}$. Generally, the ignition occurs in $\mathrm{Mg}$ through two stages: (i) formation of a loose oxide layer $(\mathrm{MgO})$ below $500{ }^{\circ} \mathrm{C}$ and (ii) the breakdown of the $\mathrm{MgO}$ layer causing the fresh metal, $\mathrm{Mg}$, to be in contact with oxygen. This leads to a high oxidation rate, triggering a rapid increase in surface temperature that is eventually followed by $\mathrm{Mg}$ ignition [21,22]. In the $\mathrm{Mg} 1 \mathrm{Ca}$ alloy, the additional oxide layer, $\mathrm{CaO}$ can be formed beside the $\mathrm{MgO}$ formation. Previous studies [3,21] have shown that the $\mathrm{MgO}$ oxide layer is thermally unstable at high temperatures (480-500) and results in the formation of the $\mathrm{CaO}$ oxide layer in the later stage of oxidation. The formation and nature of the oxide layers in $\mathrm{Mg}$ alloys are usually correlated with their ignition properties. From the reported experimental evidence, a more compact and protective $\mathrm{CaO}$ layer was formed in the $\mathrm{Mg}$ alloys containing the $\mathrm{Ca}$ element $[3,5,21]$. Hence, the improved ignition resistance observed in the current $\mathrm{Mg} 1 \mathrm{Ca}$ alloy can be explained based on the additional formation of the protective and thermally stable oxide layer: $\mathrm{CaO}$ formation with the use of $\mathrm{Ca}$ as an alloying element in $\mathrm{Mg}$.

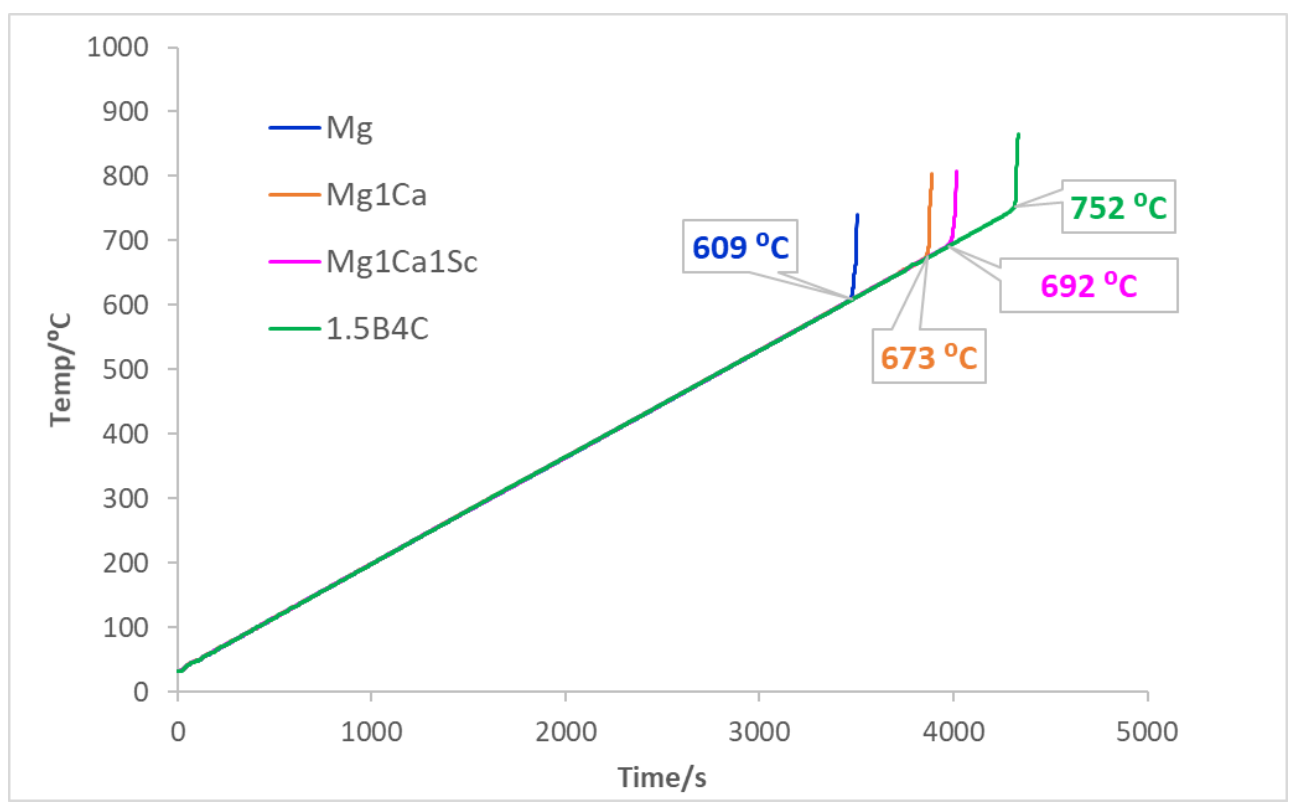

Figure 5. Ignition temperatures of $\mathrm{Mg}$, the $\mathrm{Mg}$ alloys and the $\mathrm{Mg}$ nanocomposite.

The addition of some rare earth elements such as $\mathrm{Y}, \mathrm{Gd}$, Dy, and Er have also proven to enhance the ignition resistance of $\mathrm{Mg}[2,3]$. In the current study, the rare earth element Sc was used as an alloying element in an Mg1Ca alloy. The ignition test results (Figure 5) show the improved ignition temperature in the MgCa1Sc alloy. Kim et al. [3] reported the effect of solid solubility in $\mathrm{Mg}$ alloys containing rare earth alloying elements; it was found that $\mathrm{Mg}-\mathrm{La}$ and $\mathrm{Mg}-\mathrm{Pr}$ have a low ignition resistance compared with other $\mathrm{Mg}-\mathrm{RE}$ alloys, which have medium to high solid solubility. In those alloys, solute concentration was increased during heating due to the dissolution of the secondary phases, and those elements contributed to an increase in the alloys' ignition resistance. From the $\mathrm{Mg}-\mathrm{Sc}$ binary-phase diagram [14], it can be seen that it had a solubility limit of $\sim 16$ at.\% Sc in Mg. High solute concentration in the Mg1Ca1Sc alloy can be expected, due to the high solid solubility of $\mathrm{Sc}$ in the $\mathrm{Mg}$ matrix leading to an increase in the ignition temperature. This 
indicates the beneficial effect of the Sc addition to the Mg1Ca alloy, with a higher ignition temperature being observed in the Mg1Ca1Sc alloy compared with the Mg1Ca alloy (14\%).

Regarding the $\mathrm{Mg}-\mathrm{Al}$ alloy system, solubility of $\mathrm{Al}$ is high in $\mathrm{Mg}$, yet the ignition resistance of the $\mathrm{Mg}-\mathrm{Al}$ alloy is low [3,4]. The reason for this is due to the formation of thermally unstable secondary phases; this indicates that the presence of thermally stable secondary phases is an important factor to improve ignition resistance. Previous studies on the ignition properties of magnesium-based nanocomposites have shown the enhancement of magnesium's ignition resistance due to the use of thermally stable reinforcements such as $\mathrm{B}_{4} \mathrm{C}, \mathrm{Sm}_{2} \mathrm{O}_{3}$ and $\mathrm{CeO}_{2}$ nanoparticles $[16,23,24]$. In the current study, a further increase in ignition temperature from $692{ }^{\circ} \mathrm{C}$ in the Mg1Ca1Sc alloy to $752{ }^{\circ} \mathrm{C}$ in the $\mathrm{Mg} 1 \mathrm{Ca} 1 \mathrm{Sc} / \mathrm{B}_{4} \mathrm{C}$ composite was observed (Figure 5). This clearly indicates the effectiveness of the presence of $\mathrm{B}_{4} \mathrm{C}$ nanoparticle reinforcements in improving the ignition resistance of $\mathrm{Mg}$ alloys.

With regard to microstructural analysis, in terms of grain size and distribution, finer grains and a better distribution of grain sizes were observed in the developed alloys and composite, compared with pure Mg. Grain size variation, as well as the homogeneity of grain size, is correlated to the oxide layer formation, which in turn is related to the ignition properties of the materials. The presence of high density grain boundaries (defects) can promote the formation of oxide film, since the grain boundary is susceptible to easy oxidation [25]. In addition, the differential driving force for oxidation is reduced, due to the availability of uniform grains. Hence, the presence of fine and uniform grains facilitates the formation of stable and protective oxide layers, thereby assisting in promoting the ignition temperature of the currently developed $\mathrm{Mg}$ alloys and composite $[25,26]$.

\subsection{Compressive Properties}

As shown in Table 1 and Figure 6, the compressive properties of $\mathrm{Mg}$ were enhanced in the currently developed $\mathrm{Mg}$ alloys and nanocomposite. Strength and ductility, namely the compressive yield strength ( $0.2 \%$ CYS), ultimate compressive strength (UCS) and compressive strain were improved in the $\mathrm{Mg} 1 \mathrm{Ca}, \mathrm{Mg} 1 \mathrm{Ca} 1 \mathrm{Sc}$ alloys and the $\mathrm{Mg} 1 \mathrm{Ca} 1 \mathrm{Sc} / \mathrm{B}_{4} \mathrm{C}$ nanocomposite when compared with those of pure $\mathrm{Mg}$. The least improvement of $51 \%$ CYS, $8 \%$ UCS and 23\% strain was observed in the Mg1Ca1Sc alloy. Overall, the highest compressive property increment was achieved in the $\mathrm{Mg} 1 \mathrm{Ca} 1 \mathrm{Sc} / \mathrm{B}_{4} \mathrm{C}$ nanocomposite with an improvement of $111 \%$ CYS, $20 \%$ UCS and $35 \%$ strain. The factors affecting the variation in mechanical properties of magnesium-based materials include the grain size, the size, the amount and morphology of intermetallic compounds or secondary phases and the type and nature of reinforcements used. From the grain size analysis (Figure $4 a-c$ ), a significant grain size reduction was observed in the $\mathrm{Mg} 1 \mathrm{Ca}$ and $\mathrm{Mg} 1 \mathrm{Ca} 1 \mathrm{Sc}$ alloys, compared with $\mathrm{Mg}$. Consequently, the compressive properties of the alloys were increased over pure $\mathrm{Mg}$. Although there was the same average grain size in both alloys, reduced compressive strengths and strain was found in the Mg1Ca1Sc alloy, when compared with the $\mathrm{Mg} 1 \mathrm{Ca}$ alloy. In observing the same grain sizes, as well as the similar pattern of grain size distribution, we assumed that there must have been another factor influencing the variation of compression properties between these two alloys. From the microstructure analysis, the distribution pattern of secondary phases in $\mathrm{Mg}_{2} \mathrm{Ca}$ was relatively homogeneous throughout the $\mathrm{Mg}$ matrix, with the use of a single alloying element, $\mathrm{Ca}$, in the Mg1Ca alloy. In the microstructure of the $\mathrm{Mg} 1 \mathrm{Ca} 1 \mathrm{Sc}$ alloy, most of the $\mathrm{Mg}_{2} \mathrm{Ca}$ phases were seen clustering with the $\mathrm{Mg}-\mathrm{Sc}$ phases (Figure 3). This microstructure changed the effects of the compressive properties, thereby observing reduced strength and strain in the Mg1Ca1Sc alloy, compared with the Mg1Ca alloy, despite having the same grain sizes. In the case of the $\mathrm{Mg} 1 \mathrm{Ca} 1 \mathrm{Sc} / \mathrm{B}_{4} \mathrm{C}$ composite, small clusters of secondary phases $\left(\mathrm{Mg}_{2} \mathrm{Ca}+\mathrm{Mg}-\mathrm{Sc}\right)$ were seen in the microstructure (Figures 1c and 2c). In the previous study [27], it was reported that reinforcement nanoparticles possessed the ability to assist in the breakdown of large clusters of secondary phases into small clusters. Similarly, in the present study, coarse secondary phase clusters in the Mg1Ca1Sc alloy were reduced into small clusters, with the addition of nano $\mathrm{B}_{4} \mathrm{C}$ particles in the composite material. In addition, the presence of nano 
$\mathrm{B}_{4} \mathrm{C}$ particles did not cause the nanoparticle clustering itself; instead, well distributed $\mathrm{B}_{4} \mathrm{C}$ were observed with the co-presence of $\mathrm{Mg}_{2} \mathrm{Ca}$ phases in the $\mathrm{Mg}$ matrix (Figure 2c). The combined factors of (i) a further grain size reduction of $58 \%$ compared with the $\mathrm{Mg} 1 \mathrm{Ca}$ and Mg1Ca1Sc alloys, (ii) microstructural homogeneity in terms of second phase distribution and (iii) the presence of abundant hard phases, led to the highest overall compressive properties in the $\mathrm{Mg} 1 \mathrm{Ca} 1 \mathrm{Sc} / \mathrm{B}_{4} \mathrm{C}$ composite.

Table 1. Compressive properties of the developed Mg alloys and nanocomposite.

\begin{tabular}{cccc}
\hline Material & $\begin{array}{c}\mathbf{0 . 2 \%} \text { CYS } \\
\text { (MPa) }\end{array}$ & $\begin{array}{c}\text { UCS } \\
\mathbf{( M P a )}\end{array}$ & $\begin{array}{c}\text { Compressive Strain } \\
\mathbf{( \% )}\end{array}$ \\
\hline $\mathrm{Mg}$ & $96 \pm 6$ & $342 \pm 4$ & $20 \pm 1$ \\
$\mathrm{Mg} 1 \mathrm{Ca}$ & $187 \pm 9(95 \%)$ & $403 \pm 14(18 \%)$ & $28 \pm 1(40 \%)$ \\
$\mathrm{Mg} 1 \mathrm{Ca} 1 \mathrm{Sc}$ & $145 \pm 7(51 \%)$ & $371 \pm 2(8 \%)$ & $24.6 \pm 0.3(23 \%)$ \\
$\mathrm{Mg} 1 \mathrm{Ca} 1 \mathrm{Sc} / \mathrm{B}_{4} \mathrm{C}$ & $203 \pm 2(111 \%)$ & $410 \pm 9(20 \%)$ & $27 \pm 2(35 \%)$ \\
\hline
\end{tabular}

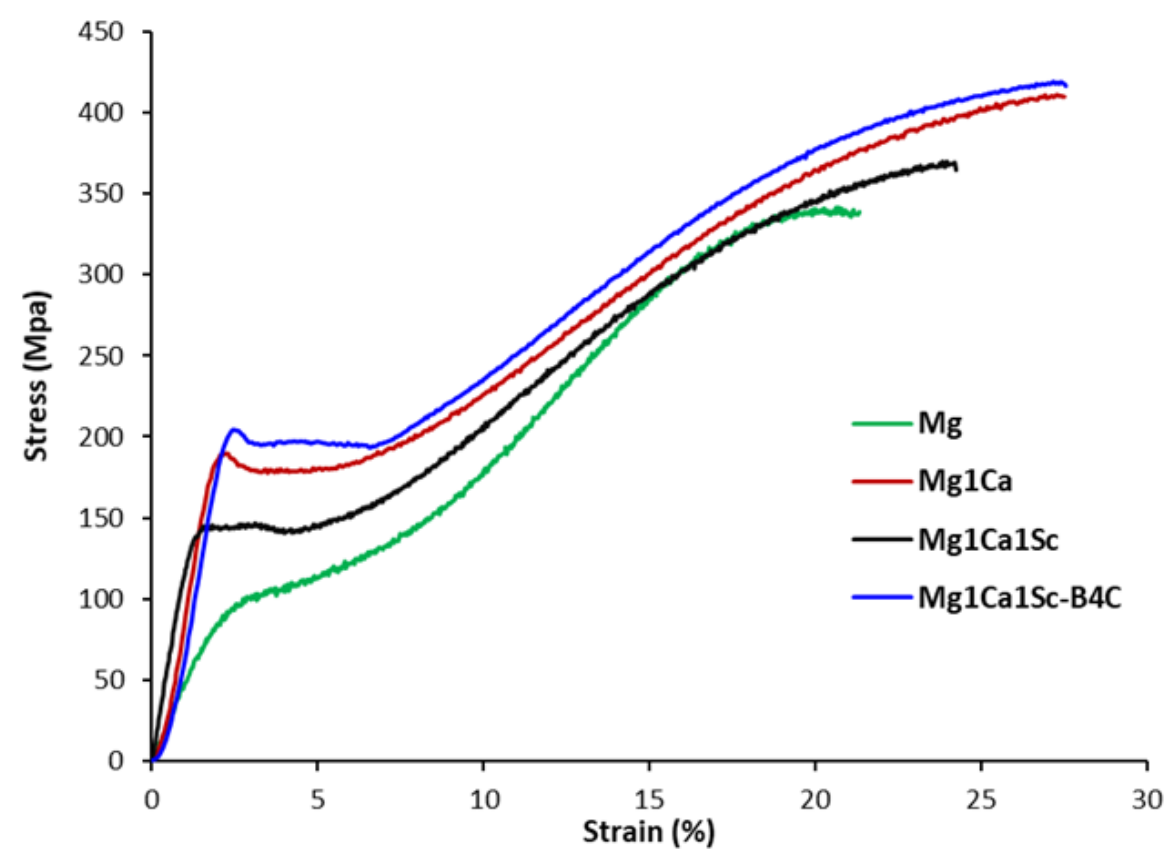

Figure 6. Compressive deformation curves of $\mathrm{Mg}$, $\mathrm{Mg}$ alloys and the $\mathrm{Mg}$ nanocomposite.

Among the commercial Mg alloys, the Elektron 21 (E21) alloy met the requirements and passed the flammability test from the Federal Aviation Administration (FAA). It is highly qualified to be used in the aviation industry [16]. E21 is composed of highdensity alloying elements such as Neodymium, Gadolinium, Zinc and Zirconium; its density is similar to the density of the AZ series $\mathrm{Mg}$ alloys $\left(\sim 1.8 \mathrm{~g} / \mathrm{cm}^{3}\right)$. In our current composite, low-density alloying elements, $\mathrm{Ca}\left(1.55 \mathrm{~g} / \mathrm{cm}^{3}\right)$ and Sc $\left(2.985 \mathrm{~g} / \mathrm{cm}^{3}\right)$ and the reinforcement phase, $\mathrm{B}_{4} \mathrm{C}\left(2.52 \mathrm{~g} / \mathrm{cm}^{3}\right)$, were used in $\mathrm{Mg}$. Accordingly, the density of the $\mathrm{Mg} 1 \mathrm{Ca} 1 \mathrm{Sc} / 1.5 \mathrm{~B}_{4} \mathrm{C}$ composite was low $\left(1.76 \mathrm{~g} / \mathrm{cm}^{3}\right)$. From the comparison results shown in Table 2, the specific yield strength of the developed composite is higher than the E21 alloy. In addition to its strength, a higher ignition temperature was also accomplished in the composite, compared with E21. Hence, this shows the potential for the Mg1Ca1Sc/1.5B ${ }_{4} \mathrm{C}$ composite to be used in the aviation industry. Further testing, such as flammability and standardization by the FAA, is still needed for the currently developed composite to be qualified as an aerospace material. 
Table 2. Comparison properties between $\mathrm{E} 21$ and the $\mathrm{Mg} 1 \mathrm{Ca} 1 \mathrm{Sc} / \mathrm{B}_{4} \mathrm{C}$ nanocomposite.

\begin{tabular}{|c|c|c|c|c|}
\hline Material & $\begin{array}{l}\text { CYS } \\
(\mathrm{MPa})\end{array}$ & $\begin{array}{l}\text { Density } \\
\left(\mathrm{g} / \mathrm{cm}^{3}\right)\end{array}$ & $\begin{array}{l}\text { Specific Yield Strength } \\
\left(\mathrm{MPa} \mathrm{cm}^{3} \mathrm{~g}^{-1}\right)\end{array}$ & $\begin{array}{c}\text { Ignition Temperature } \\
\left({ }^{\circ} \mathrm{C}\right)\end{array}$ \\
\hline $\mathrm{Mg} 1 \mathrm{Ca} 1 \mathrm{Sc} / 1.5 \mathrm{~B}_{4} \mathrm{C}$ & 203 & 1.76 & 115 & 752 \\
\hline E21 & 141 & 1.8 & 78 & 741 \\
\hline
\end{tabular}

\section{Conclusions}

This study demonstrated the systematic development of $\mathrm{Mg}$ alloys, $\mathrm{Mg} 1 \mathrm{Ca}$ and $\mathrm{Mg} 1 \mathrm{Ca} 1 \mathrm{Sc}$, to the $\mathrm{Mg}$ nanocomposite $\mathrm{Mg} 1 \mathrm{Ca} 1 \mathrm{Sc} / 1.5 \mathrm{~B}_{4} \mathrm{C}$. The resultant properties in $\mathrm{Mg}$ were due to the addition of a singular alloying element $(\mathrm{Ca})$ and a binary alloying element $(\mathrm{Ca}+\mathrm{Sc})$, in addition to the nano $\mathrm{B}_{4} \mathrm{C}$ particle reinforcement in the composite. The key points of the study can be summarized as follows:

1. In the $\mathrm{Mg} 1 \mathrm{Ca}$ alloy, the uniform distribution of the secondary phases of $\mathrm{Mg}_{2} \mathrm{Ca}$ was observed in its microstructure. The clustering of the $\mathrm{Mg}_{2} \mathrm{Ca}$ and $\mathrm{Mg}-\mathrm{Sc}$ phases were seen in the microstructure of the Mg1Ca1Sc alloy. The addition of $\mathrm{B}_{4} \mathrm{C}$ nanoparticles to the $\mathrm{Mg} 1 \mathrm{Ca} 1 \mathrm{Sc}$ alloy was effective in breaking down those coarse clusters into small clusters in the $\mathrm{Mg}$ nanocomposite;

2. Significant grain refinement was seen, with $81 \%$ grain size reduction in the Mg alloys and $92 \%$ reduction in the $\mathrm{Mg}$ composite over pure $\mathrm{Mg}$. A reasonable distribution pattern of secondary phases and/or reinforcement phases led to the grain size homogeneity in the alloys and composite;

3. A progressively higher resistance to ignition was noted with the addition of $\mathrm{Ca}$, $\mathrm{Ca}+\mathrm{Sc}$ and $\mathrm{Ca}+\mathrm{Sc}+\mathrm{B}_{4} \mathrm{C}$ in the Mg1Ca and Mg1Ca1Sc alloys and the Mg1Ca1Sc/ $\mathrm{B}_{4} \mathrm{C}$ composite. Hence, the corresponding formation of $\mathrm{Mg}_{2} \mathrm{Ca}$ and $\mathrm{Mg}-\mathrm{Sc}$ phases, and added nanoparticles, were proven to be effective in enhancing the ignition resistance of $\mathrm{Mg}$;

4. Under compressive loading, both strength and ductility were improved in the currently developed $\mathrm{Mg}$ alloys and nanocomposite. The highest overall compressive properties were achieved in the $\mathrm{Mg}$ nanocomposite due to its microstructural homogeneity (finest grain size, grain size homogeneity and uniform distribution of secondary phases) and increased presence of secondary phases $\left(\mathrm{Mg}_{2} \mathrm{Ca}, \mathrm{Mg}-\mathrm{Sc}\right.$ and $\left.\mathrm{B}_{4} \mathrm{C}\right)$;

5. It is to be noted that a higher specific yield strength and ignition resistance were also accomplished in the developed nanocomposite, when compared with the aerospace alloy, E21.

Author Contributions: Conceptualization, M.G. and S.T.; methodology, S.T. and K.S.T.; testing, characterization and formal analysis, K.S.T. and T.Y.S.B.; investigation, K.S.T. and T.Y.S.B.; writingoriginal draft preparation, K.S.T.; writing-review and editing, K.S.T. and M.G.; supervision, M.G.; project administration, M.G., S.T. and K.S.T.; funding acquisition, M.G. All authors have read and agreed to the published version of the manuscript.

Funding: This research was funded by Ministry of Education, Singapore, WBS\# R 265-000-622-112.

Institutional Review Board Statement: Not applicable.

Informed Consent Statement: Not applicable.

Data Availability Statement: Not applicable.

Acknowledgments: This research was funded by Ministry of Education, Singapore, WBS\# R 265-000622-112.

Conflicts of Interest: The authors declare no conflict of interest. 


\section{References}

1. Czerwinski, F. Controlling the ignition and flammability of magnesium for aerospace applications. Corros. Sci. 2014, 86, 1-16. [CrossRef]

2. Tekumalla, S.; Gupta, M. An insight into ignition factors and mechanisms of magnesium based materials: A review. Mater. Des. 2017, 113, 84-98. [CrossRef]

3. Kim, Y.M.; Yim, C.D.; Kim, H.S.; You, B.S. Key factor influencing the ignition resistance of magnesium alloys at elevated temperatures. Scr. Mater. 2011, 65, 958-961. [CrossRef]

4. Takeno, T.; Yuasa, S. Ignition of Magnesium and Magnesium-Aluminum Alloy by Impinging Hot-Air Stream, Combust. Sci. Technol. 1980, 21, 109-121. [CrossRef]

5. Inoue, S.; Yamasaki, M.; Kawamura, Y. Formation of an incombustible oxide film on a molten Mg-Al-Ca alloy. Corros. Sci. 2017, 122, 118-122. [CrossRef]

6. Cheng, C.; Lan, Q.; Liao, Q.; Le, Q.; Li, X.; Chen, X.; Cui, J. Effect of Ca and Gd combined addition on ignition temperature and oxidation resistance of AZ80. Corros. Sci. 2019, 160, 108176. [CrossRef]

7. Cheng, C.; Lan, Q.; Wang, A.; Le, Q.; Yang, F.; Li, X. Effect of Ca Additions on Ignition Temperature and Multi-Stage Oxidation Behavior of AZ80. Metropolitan 2018, 8, 766. [CrossRef]

8. Cheng, S.; Yang, G.; Fan, J.; Li, Y.; Zhou, Y. Effect of Ca and Y additions on oxidation behavior of AZ91 alloy at elevated temperatures. Trans. Nonferrous Met. Soc. China 2009, 19, 299-304. [CrossRef]

9. Zhang, E.; Yang, L. Microstructure mechanical properties and bio-corrosion properties of Mg-Zn-Mn-Ca alloy for biomedical application. Mater. Sci. Eng. A 2008, 497, 111-118. [CrossRef]

10. Du, Y.Z.; Zheng, M.Y.; Qiao, X.G.; Wu, K.; Liu, X.D.; Wang, G.J.; Lv, X.Y.; Li, M.J.; Liu, X.L.; Wang, Z.J.; et al. The effect of double extrusion on the microstructure and mechanical properties of Mg-Zn-Ca alloy. Mater. Sci. Eng. A 2013, 583, 69-77. [CrossRef]

11. Zhang, B.; Wang, Y.; Geng, L.; Lu, C. Effects of calcium on texture and mechanical properties of hot-extruded Mg-Zn-Ca alloys. Mater. Sci. Eng. A 2012, 539, 56-60. [CrossRef]

12. Zhou, M.; Huang, X.; Morisada, Y.; Fujii, H.; Chino, Y. Effects of Ca and Sr additions on microstructure, mechanical properties, and ignition temperature of hot-rolled Mg-Zn alloy. Mater. Sci. Eng. A 2020, 769, 138474. [CrossRef]

13. Zhao, W.M.; Zhao, Y.; Wang, Z.F.; Li, Y.Y.; Ding, J.; Xue, H.T. Effect of Mg-Nd Master Alloys on Ignition-Proof Performance of AZ91D Magnesium Alloy. Adv. Mater. Res. 2011, 214, 118-121. [CrossRef]

14. Nayeb-Hashemi, A.A.; Clark, J.B. The Mg-Sc (Magnesium-Scandium) system. Bull. Alloy. Phase Diagr. 1986, 7, 574-578. [CrossRef]

15. Sankaranarayanan, S.; Sabat, R.K.; Jayalakshmi, S.; Suwas, S.; Gupta, M. Effect of nanoscale boron carbide particle addition on the microstructural evolution and mechanical response of pure magnesium. Mater. Des. 2014, 56, 428-436. [CrossRef]

16. Tekumalla, S.; Yuan, N.J.; Haghshenas, M.; Gupta, M. Enhancing Properties of Aerospace Alloy Elektron 21 Using Boron Carbide Nanoparticles as Reinforcement. Appl. Sci. 2019, 9, 5470. [CrossRef]

17. Nayeb-Hashemi, A.A.; Clark, J.B. The Ca-Mg (Calcium-Magnesium) system. Bull. Alloy Phase Diagr. 1987, 8, 58-65. [CrossRef]

18. Dutkiewicz, J.; Rogal, Ł.; Kalita, D.; Fima, P. Development of new age hardenable Mg-Li-Sc alloys. J. Alloys Compd. 2019, 784, 686-696. [CrossRef]

19. Tun, K.S.; Zhang, Y.; Parande, G.; Manakari, V.; Gupta, M. Enhancing the Hardness and Compressive Response of Magnesium Using Complex Composition Alloy Reinforcement. Metals 2018, 8, 276. [CrossRef]

20. Sun, J.; Ma, Y.; Miao, H.; Li, K.; Li, C.; Huang, H. Effect of Ca Concentration on Microstructure and Mechanical Properties of As-Cast and As-Extruded Quasicrystal-Strengthened Mg-7.2Zn-2.4Gd Alloy. Adv. Mater. Sci. Eng. 2018, 2018, 9138753. [CrossRef]

21. You, B.-S.; Park, W.-W.; Chung, I.-S. The effect of calcium additions on the oxidation behavior in magnesium alloys. Scr. Mater. 2000, 42, 1089-1094. [CrossRef]

22. Aydin, D.S.; Bayindir, Z.; Hoseini, M.; Pekguleryuz, M.O. The high temperature oxidation and ignition behavior of Mg-Nd alloys part I: The oxidation of dilute alloys. J. Alloys Compd. 2013, 569, 35-44. [CrossRef]

23. Kujur, M.S.; Mallick, A.; Manakari, V.; Parande, G.; Tun, K.S.; Gupta, M. metals Significantly Enhancing the Ignition/Compression/Damping Response of Monolithic Magnesium by Addition of $\mathrm{Sm}_{2} \mathrm{O}_{3}$ Nanoparticles. Metals 2017, 7, 357. [CrossRef]

24. Kujur, M.S.; Manakari, V.; Parande, G.; Tun, K.S.; Mallick, A.; Gupta, M. Enhancement of thermal, mechanical, ignition and damping response of magnesium using nano-ceria particles. Ceram. Int. 2018, 44, 15035-15043. [CrossRef]

25. Merson, D.; Vasiliev, E.; Markushev, M.; Vinogradov, A. On the corrosion of ZK60 magnesium alloy after severe plastic deformation. Lett. Mater. 2017, 7, 421-427. [CrossRef]

26. Tun, K.S.; Sripathy, A.P.; Tekumalla, S.; Gupta, M. materials Development of Novel Lightweight Metastable Metal-(Metal + Ceramic) Composites Using a New Powder Metallurgy Approach. Materials 2020, 13, 3283. [CrossRef] [PubMed]

27. Nguyen, Q.B.; Gupta, M. Enhancing compressive response of AZ31B magnesium alloy using alumina nanoparticulates. Compos. Sci. Technol. 2008, 68, 2185-2192. [CrossRef] 